\title{
3 次元平行移動物体のための障害物回避経路の高速計画法*
}

\author{
柴 田昌 明** 村上俊 之*** 大 西 公 平 ${ }^{\dagger}$
}

Fast Collision-Free Path Planning for Translating Mobiler in Three-Dimensional Space

Masaaki Shibata, Toshiyuki Murakami and Kouhei Ohnishi

\begin{abstract}
This paper describes a novel method of planning collision-free path for a translating mobiler in three-dimensional workspace. The safe path is found in short calculation time by the proposed method, so that it is feasible to be applied for real-time processing. Especially, in case there exist a lot of complicated obstacles in the workspace, the advantages of the method appear more efficiently. In general collision-free path planning methods, Configuration Space is often applied. Utilization of the space is very effective to plan the safe path, but it requires so much calculation time. In this paper, in order to get the calculation time shorter, rectangular parallelepiped forbidden areas are introduced, instead of the general forbidden area in the configuration space. To apply the rectangular parallelepiped forbidden area makes the interference detection of the path against the forbidden area much easier and faster, and moreover, it makes the determination of the direction to which the path goes definite. The validity of the proposed method is confirmed in numerical experiments.
\end{abstract}

Key words : collision avoidance, rectangular parallelepiped forbidden area, configuration space, real-time processing, three-dimensional path planning

\section{1. 緒 言}

最近，柔軟な生産システムに関する研究が広く行われてい る1). 特に, 組立・分解作業においては, 環境や作業の内容 に応じて作業内容を修正してゆく自立組立ロボットの開発が 目標としてある.

組立・分解作業における部品の移動は, 製造物や環境亡の 衝突を回避しなくてはならない，これまでの大量生産型の組 立作業では, 製造物の形状が確定しており, オフラインであ らかじめ計画された経路に従って, 部品を取付け部位へ安全 に移動させることができる. 一方, 将来的な, 個々の製品の 形状がそれぞれ微妙に異なる多品種少量生産ラインでは，そ れぞれの部品のための非衝突経路を逐一計画する必要がある. 同様に分解作業では, 工作物の形状か，生産段階で用いられ た情報 (知識テータベース) と異なっている可能性があるこ とを考虑すれば, リアルタイムでの形状認識と同時に, 経路 を再計画する必要がある. このように動的なシステムでは, 経路計画に即応性が要求される.

そこで本稿では, 障害物回避を考虑した 3 次元経路の高速 な計画方法を提案する. 非衝突という点では, 製造物に対す るアクチュエータの衝突と, 部品の衝突を考虑しなくてはな らない.アクチュエータの衝突回避は非常に重要であり, 多 くの研究が為されている. しかし, 取付け部位に最も接近す るのは部品であり, また, 適切な組立手順が得られる場合, アクチュエータの衝突よりも，むしろ部品の衝突の危険性が より高いと思われる. このような観点から, 部品の障害物回 避を中心に考虑した安全な移動経路の生成を考える. そして, これをさらに一般化し，3次元空間において並進運動をする 物体のための障害物回避経路の計画問題として考える.

\footnotetext{
* 原稿受付 平成 7 年 2 月 17 日

** 学生会員 慶應義塾大学理工学部（横浜市港北区日吉 3-14-1）

*** 慶應義塾大学理工学部

†正 会 員 慶應義熟大学理工学部
}

\section{1 これまでの経路計画問題}

これまでの経路計画問題では， 2 次元作業空間を有する移 動体についての研究が多く為されている. 2 次元問題では, 特に, 経路長が最短であるものを発見する方法について議論 されることが多い. 単純化された 2 次元最短経路問題は, グ ラフ検索問題として考えられるので, Dijkstra の方法 ${ }^{2}$ など により簡単に求められる. 以後, グラフ検索方法の高速化が 図られるなどして, 非常に効率の良い手法が示されるにまで 至った3)4)．さらに，障害物の占める領域の形状に関する制 約の緩和を考虑した問題についての研究もある ${ }^{5)}$.

一方, 3 次元問題では, 問題が複雑になり， 2 次元の場合の ように考えることが容易でない，2次元問題の解法を，直接 に 3 次元問題へ適用できる場合はまれである. Lozano-Pérez ら6) による初期の経路計画問題では，凸多角形もしくは凸 多面体である障害物について，拡大障害物を適用することて 問題の簡単化を図る方法 ( 可視グラフ法 ) が示されている. この方法は, コンフィグレーション空間 ( 以下 C 空間と呼 ぶ ) を生成・利用した手法として知られている.C 空間の利 用は, 経路計画問題の簡単化のために非常に有効な手段とし て広く用いられている. しかし, 部品や環境が複雑な形状で あって, それらを精確に認識し, 経路を計画したい要求があ る場合, 時間的コストの観点からすれば, C 空間の利用はあ まり有利な手法とは言えない.

さらに, C 空間が生成された後にも, 経路探索のために多 くの演算が必要となる. 拡大障害物が多くの面を有し, それ らの面が任意の形状である場合, 経路との干涉判定に多くの 時間を費やすことになる. このように， 3 次元問題は，任意 の可能解を得ることすら容易ではなく, まして, 最短経路問 題に至っては, NP-hard であることが示されており7), その 求解には障害物数および拡大障害物の頂点数に関しての指数 オーダの計算量が必要であることが予想されている8).

提案する方法では, 経路長の最適性を問わずに, 演算量の 
低減による高速な求解を主眼に置いて経路計画を考えている. よって, 計画される経路は最短ではないが, より適切な可能 解を求めるとする. C 空間で用いるような禁止領域の生成を 極力おこなわず, これに代わる直方体禁止領域を導入し, 経 路を探索することで, 記憶データの少量化, 処理時間の短縮 を図っている.

\section{3 次元経路計画問題}

前章でも触れたように, 部品の移動に際して衝突を回避す べき障害物之なるのは製造物である．その位置及び形状は センサ等によってリアルタイムで認識されると仮定する，そ して, これらの情報が取得され次第, 移動経路の算出を実行 する.

部品および製造物については任意の形状を許容する．そし て，これらをすべて平面からなる多面体として表す．曲面部 分は複数の平面を組み合わせることで表現するが, 細かく数 多くの平面を適用することで精度を確保する．本手法の計算 時間オーダは，それらの多面体の面数にあまり依存しないの で, 多面体を複雑に表現する必要のある場合に, より効果を 発揮する.

このように部品および環境をとらえることで, 本問題は幾 何モデに基づく経路計画問題として扱うことができる. 以 下に，本稿にて述べる経路計画問題を明確化する.

3 次元作業空間において, 体積を有する移動体のための経 路を計画する. 移動体については，任意の方向への移動が可 能であるとし，回転運動しないことを制約とする，移動体の 初期状態における出発地点, および最終状態における目的地 点の 2 点が, 作業空間内の任意の位置に指定される. 回転運 動についての制約から，移動体は目的地点に到達するまで, 初期状態における姿勢を保って平行移動を行うことになる. 移動体は単体で移動するとし，これを支持するものなどは考 虑しない，またその形状は，任意の凸多面体により表現され， 変形をしない.

作業空間内に存在する障害物も体積を有し，任意の多面体 によって表現されるとする．これらは，必ずしも凸である必 要はない. しかし, 任意の多面体は, 複数の凸多面体を組み 合わせたものとして認識できるので, 実際は, 凸多面体障害 物のみを対象として考えればよいことになる.すべての障害 物は，空間に固定されているとする.

\section{3. 直方体禁止領域の算入}

多数の障害物が作業空間内に存在する場合でも,すべての 障害物を迁回する必要があるわけではない，不要な禁止領域 の生成を省くことで, 処理全体の高速化を図ることができる. そこで, 禁止領域を表す拡大障害物に代わる直方体禁止領域 を定義し, 経路計画のためのプリプロセスにかかる時間コス トの低減を図る.

3.1 コンフィグレーション空間

前章にて示した経路計画問題に，従来の C 空間を適用した 場合に生じる，高速処理には有利でない点について触れる.

移動体が回転運動をしないという制約から，C 空間は作業 空間之同次元の座標系を有する. このとき, 空間内の禁止領 域は，障害物ごとに求められる抎大障害物の占める領域とし て定義される.そして, 移動体の位置は $\mathrm{C}$ 空間内の一点之

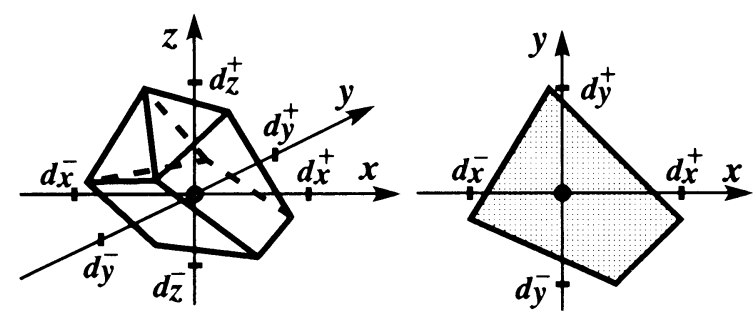

(a) 3-Dimensional Model

(b) 2-Dimensional Model

Fig.1 6-Extremal points of mobiler

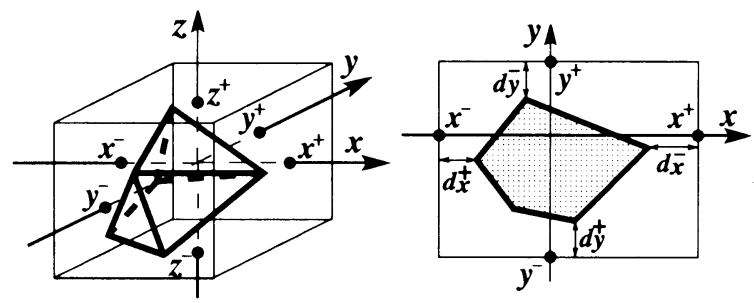

(a) 3-Dimensional Model

(b) 2-Dimensional Model

Fig.2 Rectangular parallelepiped forbidden area

して表現される. 計画される経路は線分列によって表される ので, $\mathrm{C}$ 空間の利用には，このように経路の計画が簡単化さ れるという利点がある.

ところか，拡大障害物の生成には，移動体の頂点之障害物 の面, および移動体の面と障害物の頂点による接触面を計算 する必要がある. したがって, それらが多くの面, 頂点を有 する場合，膨大な演算量を要し，ひいては処理時間に悪影響 を及ぼす，そして，C 空間全体を得るためには，すべての障 害物について挔大障害物を生成することになる.

\section{2 直方体禁止領域}

拡大障害物を求める代わりに，これに外接する直方体領域 を導入し，その定義および生成法について述べる.

まず，移動体の頂点について，“東西南北上下”の $6 \supset 0$ 端点を見つける. 図 1 に示すように, 移動体の中心点を原 点とする局所座標系を考えるとき，それらの端点を含み，そ れぞれ $\mathrm{x}$ 軸, $\mathrm{y}$ 軸， $\mathrm{z}$ 軸に直交する平面の各軸に対する交 点を $\left\{d_{x}^{+}, 0,0\right\},\left\{0, d_{y}^{+}, 0\right\},\left\{0,0, d_{z}^{+}\right\},\left\{d_{x}^{-}, 0,0\right\},\left\{0, d_{y}^{-}, 0\right\}$, $\left\{0,0, d_{z}^{-}\right\}$とする. 元の障害物についても 6 つの端点を明ら かにした上で, 例えば, 北側の端点から $\left|d_{y}^{-}\right|$だけ北側に位 置する点を含み, $\mathrm{y}$ 軸に直交する平面 $y=y_{i}^{+}$を考える. 同 様にして, 元の障害物から $\left|d^{ \pm}\right|$だけ離れた平面を 6 方向に ついて求め, 図 2 に示すような, これらの面からなる直方体 領域を定義する.

以下，このような昖大障害物に外接する直方体を“直方体 禁止領域々と呼ぶことにする. この領域は，元の障害物に対 する拡大禁止領域に外接している. しかし，6つの面の決定 には，拡大障害物を明らかにする必要はなく，元の障害物の 6 つの端点の位置と, 移動体の 6 つの端点の位置が得られれ ば, 容易に求めることができる.

ここで, 次章にて述べる経路計画のために，直方体禁止領 域の $6 つ の$ 面について, 位置に関するソートを実行し, ラベ ル付けをしておく，この操作は, 計画される経路と禁止領域 との干涉判定の際の時間コストの低減に有効となる. 


\section{4. 経路計画アルゴリズム}

\section{1 基本戦略}

直方体禁止領域が求められた空間においての 3 次元経路計 画法の基本的手順を示す. 参照のために，図 3 に 2 次元モテ ルでの探索の様子を示す.

Step 1. 経路端点の現在位置（初期地点）及び目的地点の 2 点間を線分で結んだ経路を考える.

Step 2. 線分経路と直方体禁止領域との干涉を判断する. 現 在位置に最寄りの干涉地点を発見し、この地点まで前 進する. 干涉が無い場合は終了.

Step 3. 干涉した禁止領域に対する迁回経路を計画する.

Step 4. 迂回経路に従って前進し，その禁止領域の表面を離 脱可能な点まで到達する. この後, Step 1 に戻り, 以 上の手順を繰り返す。

干涉判定では，経路端点の現在位置と目的地点を対頂点と する直方体領域に掛かる直方体禁止領域を対象として限定す る. 直方体禁止領域を生成する過程で，各面が位置に関して ソートされているので, $x, y, z$ 軸に沿って順次, 効率よく 判定してゆける. 計画されてゆく経路の端点が, 次第に目的 地点へと近づいて行くので，干涉判定の対象となる直方体禁 止領域の数が徐々に減り, 干涉判定の試行回数が減少してゅ く.さらに，すべての面が長方形であることから，経路と面 との干涉判定は非常に容易である.

また， 3 次元経路計画を難しくしている問題の一つが迁回 経路の計画であるが，これについては次節にて述べる.

このように, 前進・迁回を繰り返しながら経路が計画され る. 前進や迁回の各フェーズにおいては, 局所的に最短経路 計画を企図する手法を採用する．全体的に最短である経路は 得られないか，比較的良好な経路が計画されることが期待で きる.

\section{2 迂回経路の計画}

経路端が直方体禁止領域の表面上に到達した場合, その領 域表面をたどり離脱まで至る迁回経路を計画する．３次元多 面体の表面上の 2 点の最短経路計画については多くの研究が あり, 障害物の頂点数あるいは面数を $M$ とした場合, 計算

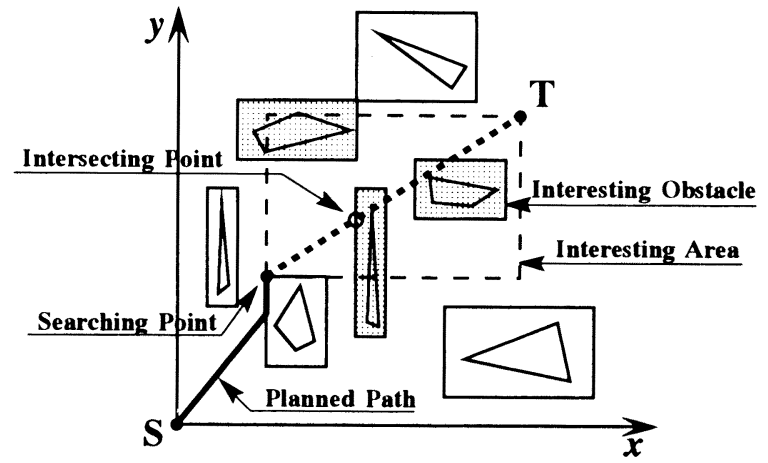

Fig.3 Path planning in 2-D workspace model

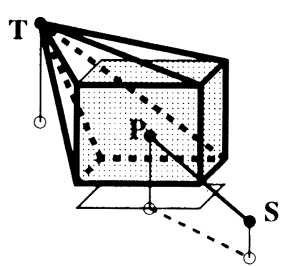

Fig.4 Nonahedron on which shortest path exists
オーダ $O\left(M^{2} \log M\right)$ の手法などが示されている8)9). また, 障害物を 1 つに限った場合では $O\left(M^{2} \log M\right), 2$ つの場合 では $O\left(M^{3} \log M\right)$ のオーダで計画されることが示されてい $3^{8) 10)}$.

しかし，今，我々の扱う障害物は直方体であることから， より有利なオーダで解くことができる. 図 4 は, 経路端点が 直方体禁止領域 ( 色付き部分) の表面上の点 $\mathbf{P}$ に到達した 状況を示す．経路が到達した直方体以外のすべての直方体禁 止領域を無視して，この直方体の表面の一部之目的地点を含 む仮想面からなる仮想凸多面体（太線）を考える. 図 4 の 場合, 直方体領域の 3 面之, 目的地点を含む $6 \supset 0$ 角形で 構成される 9 面体であるが，これ以外にも目的地点の位置に よって 5 種類の形状の多面体がある. 経路端点之目的地点を 結ぶ最短経路は，その凸多面体の表面上に存在する．経路端 点之目的地点の位置関係から 5 つの仮想多面体のう.ち 1 つが 直ちに選ばれる.いずれの仮想多面体についても, 最短経路 長を与える有効な経路のパターンは, あらかじめ想定が可能 であり, 各パターンにおける経路の算出は, 単純な一次式か ら得られ，候補となる経路の経路長は容易に算出される. そ の経路パターンの数は, 最も多い仮想多面体の場合でも 20 とおりが存在する. つまり, 最悪の場合でも 20 の経路の経 路長を比較することにより最適解が得られる. したがって, 計算オーダは $O(1)$ である.

ただし，このようにして求められる経路は，仮想多面体に 内包されている直方体以外の直方体禁止領域を無視して計画 されている. 実際には，直方体領域が重なり合った状況を考 虑する必要から, 直ちにそれを安全な経路であると断定でき ない. したがって, 他の直方体領域との干涉判定を行いなが ら経路をたどって行き, 干涉が発生するまで, 計画された経 路に沿って前進して行くとする.

\section{3 重なり合う直方体禁止領域}

複数の直方体領域が重なり合っている箇所では, 図 5 に示 すような凹稜 (Concave Edge), 凹頂点 (Concave Vertex), 鞍頂点 (Saddle Vertex) などが存在するため, 探索される経 路が目的地点へ向かって一样に接近することはできない.

図 6 に示すように, 経路が 1 つの直方体領域の表面上の点 $\mathbf{P}$ に到達した場合，前節にて述へた方法によって，その表面 上をたどる迁回経路を計画し，それに従って前進する.ここ で，2つ目の直方体禁止領域に点 $\mathbf{Q}$ で衝㔖したと仮定する.

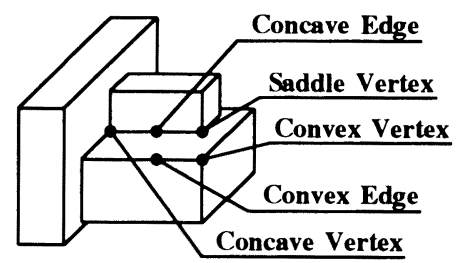

Fig.5 Terms of parts of rectangular parallelepiped

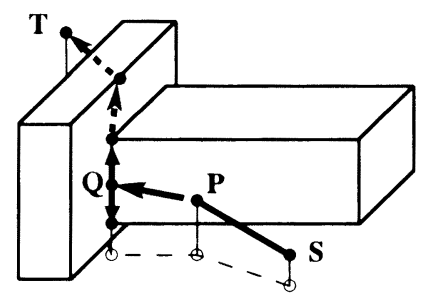

Fig.6 Detouring path along concave edge 
次に，点 $\mathbf{Q}$ が存在する凹稜に沿った 2 方向のうち、いずれ かの方向を選択し，前進する.

Case 1. 2点とも鞍頂点の場合 一目的地点に近い方を選択 Case 2. 鞍頂点と凹頂点の場合 $\longrightarrow$ 鞍頂点を選択

Case 3. 2点とも凹頂点の場合 $\longrightarrow$ 目的地点に近い方を選択

鞍頂点に至った場合，再び，前節で述べた方法を適用し， 直方体禁止領域の表面をたどる迁回経路を計画する．また， 凹頂点に到達した場合には，たどってきた凹稜以外の $2 つ の$ 凹稜の一方を選択し，これに沿って前進する．この選択は上 記の方法に準ずる.

すべての移動に際し, 到着した地点が, 過去に到着したこ とがあるかどうかを判断する. 既に通過していた場所であっ た場合はバックトラックし，それまでに分岐があったところ まで後退して, 試行していない方向に前進する.これにより, すべての可能性のある経路が試行され, また, 無限ループが 回避される. もし, 目的地点が複数の直方体禁止領域によっ て完全に取り巻かれている状態になければ, 可能解が実在し, 目的地点へ向かう経路は必ず発見される.

しかしながら, 目的地点が直方体禁止領域の内部に含まれ てしまっている場合, あるいは複数の直方体禁止領域によっ て取り囲まれている場合, 目的地点への到達は不可能となる. そこで, 直方体禁止領域の一部を拡大障害物に置き換えるた めの ‘切削' を行う.

\section{4 直方体禁止領域の切削}

直方体禁止領域の一部を, 内包されている拡大障害物の面 に沿って切削し, 部分的に正味の禁止領域を求める作業を“直 方体禁止領域の切削' と呼ぶことにする.もし, 直方体領域 の全部を切削すれば, 内包される拡大障害物を求めることと 同義になる. 本手法では, 必要な個所のみを切削することで, 切削に要する計算時間の低減と, 経路計画時の衝突判定の試 行回数の增加の抑制を図る.

まず, 切削の具体的な方法を述べ. 図 7 に, 経路端点が 凹稯上に到達した状況を上から見た様子を表す.はじめに, 点 $\mathbf{Q}$ を含む直方体禁止領域の面は, 頂点 $\mathbf{A}$ および頂点 $\mathbf{B}$ を参照して决定されている. それらの頂点と移動体の面とが 接した状態で作る平面で直方体領域を切削する. 次に， $\mathbf{A}$, $\mathbf{B}$ を含み $\mathbf{Q}$ の方向に向いた面之, 移動体の頂点の為す平面 で切削する. 移動体の頂点数 $K$, 面数 $O(K)$, 障害物の最大

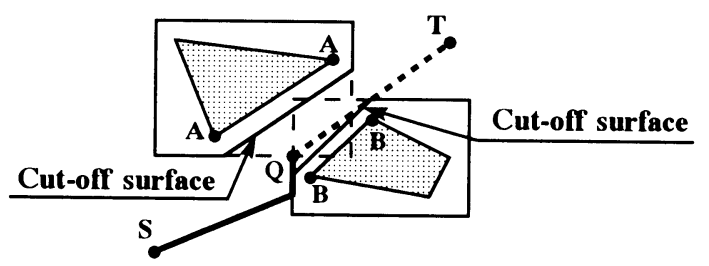

Fig.7 Cut-off of overlapped forbidden area (Top view)

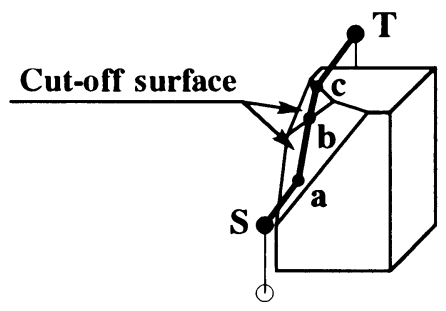

Fig.8 Detouring path on cut-off surface

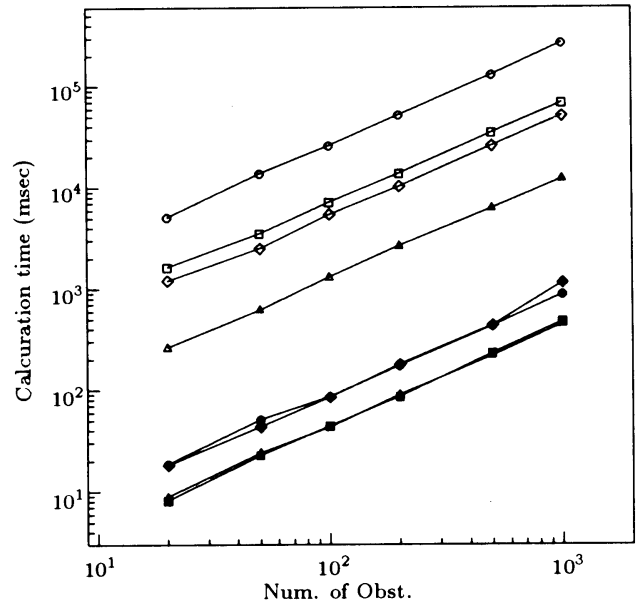

\begin{tabular}{|c||c|c|c|c|c|c|c|}
\cline { 3 - 8 } \multicolumn{2}{c|}{} & \multicolumn{4}{c|}{ Mobiler's } & \multicolumn{3}{c|}{ Obstacles' } \\
\cline { 3 - 8 } \multicolumn{2}{c|}{} & Vertices & Edges & Planes & Vertices & Edges & Planes \\
\hline \multirow{3}{*}{ Proposed } & & 20 & 40 & 12 & 12 & 40 & 18 \\
Method & 20 & 40 & 12 & 5 & 9 & 6 \\
& - & 5 & 9 & 6 & 12 & 40 & 18 \\
& & 5 & 9 & 6 & 5 & 9 & 6 \\
\hline Only for & $\bigcirc$ & 20 & 40 & 12 & 12 & 40 & 18 \\
Generating & $\square$ & 20 & 40 & 12 & 5 & 9 & 6 \\
C-Space & $\diamond$ & 5 & 9 & 6 & 12 & 40 & 18 \\
& $\triangle$ & 5 & 9 & 6 & 5 & 9 & 6 \\
\hline
\end{tabular}

Fig.9 Simulation results

頂点数 $M$, 面数 $O(M)$ を用いて, 切削に費やす計算時間の オーダは $O(K M)$ となる.

切削された後の禁止領域を迁回する方法を示す．基本的な 戦略は、これまでに示した手法と同様だか，切削された禁止 領域の形状は任意の凸多面体であるため, 効率の悪い方法之 なる.

図 8 に示すように, 切削面上に到達した場合 ( 点 a ), ま ず, 到達した面以外のすへてて禁止領域を無視した最短経路 計画を行う. 図中では, 経路 a-b-T が最短経路である. こ の経路に㳂って, 点 $\mathbf{b}$ まで前進する. 次に, 点 $\mathbf{b}$ から $\mathbf{T} へ$ 至る最短経路を計画する。 これにより, 経路 b-c-T が得ら れる. 同様にして, 点 $\mathbf{c}$ まで前進し，禁止領域表面を離脱 する.

このように直方体禁止領域の切削によって, 可能解が発見 不能になる事態が回避される.

$$
\text { 5. シミュレーション }
$$

提案されたアルゴリズムに基づいて計算機シミュレーション を行った. シミュレーションには, Workstation SUN SPARC Classic を用いた. また, 以下に示される計算時間には, ハー ドティスク等の外部記境装置へのアクセス時間を含んでい ない.

作業空間の状況として, 移動体の (頂点数, 稜数, 面数) は, $(5,9,6)$ および $(20,40,12)$ の 2 通り，また，障害物は $(5,9,6)$ および $(12,40,18)$ の 2 通りを用い, 都合 4 通りの 組合せについて実行した. それぞれの場合について, 20, 50, $100,200,500,1000$ 個の障害物を設定しており, 個々の障害 物の形状・大きさはすへててランダムに上.えてある. 示された 結果は, 100 回試行の平均値を探用している.

\section{1 結果}

図 9 は, 障害物数に対する経路計画に要した計算時間の 
Table 1 Shared time for path planning per total time

\begin{tabular}{|c|c|c|c|c|c|c|}
\hline \multicolumn{3}{|c|}{ Mobiler's } & \multicolumn{3}{|c|}{ Obstacles' } & \\
\hline $\mathrm{V}$ & $\mathrm{E}$ & $\mathrm{P}$ & $\vec{V}$ & $E$ & $\mathrm{P}$ & \\
\hline 20 & 40 & 12 & 12 & 40 & 18 & $6.2-15.1 \%$ \\
\hline 20 & 40 & 12 & 5 & 9 & 6 & $9.3-24.7 \%$ \\
\hline 5 & 9 & 6 & 12 & 40 & 18 & $5.3-28.4 \%$ \\
\hline 5 & 9 & 6 & 5 & 9 & 6 & $6.6-21.7 \%$ \\
\hline
\end{tabular}

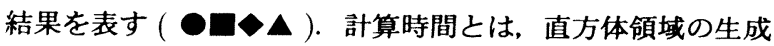
と経路の計画に要した時間を意味する.ささらに, 図 9 には, $\mathrm{C}$ 空間を生成した場合に要する計算時間を比較・対照のため にあわせて示してある $(\bigcirc \square \diamond \triangle)$. これには, 経路計画の 時間を含んでいない.

また，表 1 は，計算時間全体における経路探索に費やし た時間の比率を表す.

\section{2 検討}

$\mathrm{C}$ 空間の生成は, 1 つの障害物につき, 4.4 節にて示した 直方体領域の切削之同様の計算量が必要となる. 移動体の頂 点数 $K$, 障害物の頂点数 $M$, 障害物数 $N, L=N M$ とし て, 計算オーダは $O(K L)$ となる. 結果からも線形性が見え る. 接触判定を迅速に行うためには, 禁止領域の面について の位置や領域の情報などを保持しておくために，元の障害物 についての情報 $O(L)$ の 2 倍以上の記境容量を必要とする. そして, これらの情報を用いて接触判定が行われることから， 経路計画の時間コストを增大させる原因にもなる.

他方, 直方体禁止領域の生成に要する計算オーダは, 作業 空間内の障害物の総頂点数 $L$ に依存する．6つの端点を発見 するために $6 L$ 回の比較を行うためで, $O(L)$ となる. また, これとは別に，面検索のためのソートに $O(L \log L)$ を費や す. しかし, シミュレーション結果から、この程度の障害物 数では, 面検索のためのソートによる時間への影㗽は無いこ とがわかる. また, 保持すべき情報は, 元の障害物の位置お よび直方体領域の 6 面の位置であり，6面の情報は，1つの 直方体禁止領域あたり, $6 つ の$ 值 $\left\{x_{i}^{+}, y_{i}^{+}, z_{i}^{+}, x_{i}^{-}, y_{i}^{-}, z_{i}^{-}\right\}$ である. 元の障害物のために $O(L)$, 直方体禁止領域のため に $O(N)$ の記憶容量を使用する. 切削の行われていないと ころでは，この 6 つの值のみを用いて接触判定をするので， 経路計画の際の時間短縮に効果を上げていると思われる.

結果に示される時間のみを単純比較すれば, $10 \sim 100$ 倍の 高速化が得られていることがわかる. しかしながら, 本手法 は経路計画までを含めて, 有効性が評価されるべきなのて， 経路計画についての検討を同時に考虑しなくてはならない. C 空間を用いて経路を計画する何らかの手法と比較したとす れば，それ以上の高速化が図られていると言える.

表 1 は，各条件の下，処理時間全体に対する経路探索に費 やした時間の比率を示す. 経路計画の計算オーダは, 経路端
か值方体禁止領域と干涉した回数, および凹頂点や鞍頂点て 生じる経路探索のための分岐の回数に依存する. 各分岐にお いては, 2 方向が選択されるので, 分岐回数を $R$ とすると き, $2^{R}$ とおりの経路が候補として存在することになる.よっ て, 経路計画の計算オーダは $R$ に関して指数的となること が予想されるが, 表 1 を参照すれば, 経路計画が短時間て 行われていることがわかる.

\section{6. 桔}

与えられた環境情報の幾何モデルに基づいて 3 次元非衙突 経路を高速に計画する手法を示した. 本手法は, 直方体禁止 領域を導入することで, 以下に挙げる高速化のための効果を 得た.

（1）正味の禁止領域を求めるための計算時間および使用 する記億容量に比較して，低コスト化が図られた.

(2) 干涉判定において, 対象となる面が長方形であるこ とから判定方法が非常に簡単であり，また，ソートで きることから必要な判定のみを実行することが可能て ある.

（３）迁回すべき領域が直方体であることを利用した局所 的最短経路の計画法が適用でき, あらかじめ想定され た候補経路の中から選択されうる. さらに，それら候 補経路の経路長は, 単純な 1 次式によって与えられる ので, 直ちに最短解が得られる.

シミュレーションにおける障害物の数やそれらの形状につ いては，実用を念頭に置いた適切な条件を用いており，その 結果より，提案された手法が本稿の冒頭にて述へたようなリ アルタイム処理に十分対応しうることが示された.

\section{考文 献}

1) “特集・知的生産システム”, 真気学会誌, 114, 12, (1994) 785.

2) E.W. Dijkstra : A Note on Two Problems in Connection with Graphs, Numer. Math., 1, (1959) 269.

3) E. Welzl : Constructing the Visibility Graph for $n$ Line Segments in $O\left(n^{2}\right)$ Time, Inform. Proces. Lett., 20, (1985) 167.

4) M. Fredman and R.Tarjan : Fibonacci Heaps and their Uses in Improved Network Optimization Algorithms, J. ACM, 34, 3, (1987) 596.

5）劉雲輝，有本卓：一般的形状の障害物が存在する棵境における移動 ロボットの経路計画法, 日本ロボット学会誌, 9, 2, (1991) 184.

6) T. Lozano-Pérez and M.A. Wesley : An Algorithm for Planning Collision-Free Paths among Polyhedral Obstacles, Comm. ACM, 22, 10, (1979) 560 .

7) J. Canny and J. Reif : New Lower Bound Techniques for Robot Motion Planning Problems, Proc. 28th FOCS, (1987) 49.

8) M. Sharir and A. Schorr : On Shortest Paths in Polyhedral Spaces, SIAM J. Comput., 15, 1, (1986) 193.

9) J.S.B. Mitchell, D.M. Mount and C.H. Papadimitriou : The Discrete Geodesic Problem, SIAM J. Comput., 16, 4, (1987) 647.

10) M. Sharir : On Shortest Paths amidst Convex Polyhedra, SIAM J. Comput., 16, 3, (1987) 561. 